\title{
MINERAL SALTS IN CONTROLLING POWDERY MILDEW OF SQUASH
}

\author{
MUHANNA, NAGLAA A.S., SEHAM S.M. RAGAB AND GEHAD M. MOHAMED \\ Plant Pathology Research institute, ARC, Giza , Egypt.
}

(Manuscript received 26 May 2011)

\begin{abstract}
Powdery mildew of squash caused by Sphaerotheca fuliginea is more prevalent in Egypt, in Summer and Nili plantations than in the Winter. The effect of spraying different salts on disease incidence was studied. Results revealed that $\mathrm{KCl}, \mathrm{KH}_{2} \mathrm{PO}_{4}$ and $\mathrm{K}_{2} \mathrm{CO}_{3}$ were generally effective in powdery mildew control. It was also concluded that potassium salts at concentrations of $750 \mathrm{ug} / \mathrm{ml}$ decreased infection, as compared with the fungicide Prochloraz either applied after or before symptom development. Biochemical changes associated with salt application possibly induced systemic resistance. The presence of common protein bands were recognized. Electrophoretic analysis of extracted proteins on polyacrylamide gel showed greater number of protein bands with fungicide treatment as compared with $\mathrm{K}_{2} \mathrm{CO}_{3}, \mathrm{KCL}, \mathrm{KH}_{2} \mathrm{PO}_{4}$ and the control.

key word: Squash, Powdery mildew, Salt, Sphaerotheca fuliginea, Resistante, and Pathogensis-Proteins.
\end{abstract}

\section{INTRODUCTION}

Squash (Cucurbita pepo L.) is one of the most important vegetable crops in Egypt. It is cultivated mainly at three dates, locally defined as Winter, Nili and Summer plantations. The total area planted in Egypt reached 88372 feddans in 2008, producing approximately 651589 tons of marketable fruit, (Dept.Agric.Stat.,Min.Agric., 2008). Squash plants are subject to several diseases, causing great losses in yield and quality. Disease distribution differs according to the season of plantation ,powdery mildew caused by Sphaerotheca fuliginea (Schlechtend:fr). is a widespread and important disease .

Although Cucurbita species are susceptible to powdery mildew, symptoms may not be recognized totally on melon cultivars . Plants are known to acquire local and systemic resistance against pathogens in response to primary infection (Sequeira , 1983). The principal effect of the disease on squash may be manifested in decreasing furit size and fungicidal sprays are a basic aspect required for the disease control (Sherf \& MacNab, 1986) . It has been reported that some phosphate salts could induce local and systemic resistance to various plant diseases including powdery mildew of cucumber (Mucharromah \& Kuc, 1991). Meanwhile, other inorganic salts 
such as sodium bicarbonate (Ziv \& Zitter, 1992) and lithium chloride (Abood et al 1991) were found to have some inhibitory effects on Sphaerotheca fuliginiea.

In trials to explain the effect of physiological and chemical changes following salt (s) application. Bourlarye et al (2005) reported that biochemical analyses showed similar levels of 4-coumarate:CoA ligase (4 CL), protein accumulation for all treatments. However, the results support the idea that induced resistance in cucumber is largely correlated with rapid de novo biosynthesis of flavonoid phytoalexin compounds.

Reuveni et al (1995) found that the powdery mildew infection on cucumber was significantly controlled by a single spray of aqueous soluations ( $25 \mathrm{mM}$ ) containing various phosphates and potassium salts which also reduced the production of conidia from colonies.

Nam Jun Kang (2008) found that the powdery mildew infection on cucumber was significantly reduced by foliar application of a mixture of riboflavin and methionine (RM). The effects of fungicidal activity on leaves applied with RM were detected through restriction of progress of colonies and disease severity compared with control plants. Protein analyses revealed that the bands increased after application as compared with the control .

The present work is concerned with evaluating the effect of spraying inorganic salts at different concnterations on powdery mildew disease incidence and severity and to explain their possible modes of action on squash.

\section{MATERIALS \& METHODS}

\section{Greenhouse experiment}

Domestic squash cultivar(Eskandarany) susceptible to Sphaerotheca fuliginea (Schlecht. Ex Fr. Pol), race 0,1 and 2, (Ahmed et al 2000) was used. Five seeds were sown per pot (30 cm dimater) containing a sandy loam soil under greenhouse conditions $\left(20-24 c^{0}\right)$, in five replicates .

\section{Pathogenicity and inoculation}

For inoculation, the conidia of $S$. fuliginia were collected from naturally infected leaves of squash plant. Conidal suspensions in sterilized water, were adjusted to $3 \times 10^{4}$ conidia / $\mathrm{ml}$, then atomized onto the upper leaf surface of squash plants. The treated plants were separated into two groups :

1) Plants of the first group were inoculated with $S$. fuliginia ( $3 \times 10^{4}$ conidia/ $\mathrm{ml}$ ) at the second and third leaf phase, then received the treatment concernced . 
2) The second group was prepared in the same way mentioned before, except inoculation with the fungus was carried out 3day after mineral salt or fungicide treatments.

\section{The treatments included}

$$
\begin{array}{lc}
\text { 1- Potassium dihydrogen phosphate } & \mathrm{KH}_{2} \mathrm{PO}_{4} \\
\text { 2- Potassium chloride } & \mathrm{KCl} \\
\text { 3- Potassium carbonate } & \mathrm{K}_{2} \mathrm{CO}_{3} \\
\text { 4- Prochloraz ( Master 25\%) } & \\
\text { 5- Control unsprayed plants } &
\end{array}
$$

Solutions were prepared and used at concenteration of 250,500,750 ug/ml and $1 \mathrm{ml} / \mathrm{L}$ for the fungicide treatment.

Disease assessment: Disease severity was estimated on an arbitrary scale of (0-5) of Descalzo et al(1990)., where,

$0=$ no mildew colonies observed

$1=1-25$ colonies/ leaf

$2=26-50$ colonies/leaf

$3=51-75$ colonies/leaf

$4=76-100$ colonies/leaf

$5=>100$ colonies per leaf.

Disease severity $=\frac{\left.\sum \text { (disease rating } \mathrm{x} \text { number of leaves of that specific rating }\right)}{\text { Maximum rating of disease severity per test leaf } \mathbf{x} \text { total of test leaves }} \times 100$

\section{Protein extraction and electrophoretic analysis}

Sampled leaves were collected from different treatments and kept frozen at ($80^{\circ} \mathrm{C}$ ) till use,according to the method of Laemili(1970), however $\mathrm{N}, \mathrm{N}, \mathrm{N}, \mathrm{N}-$ Tetra methyl ethylene diamine (TEMED) was reduced to 25ul and Ammonium per sulphate solution (APS) was reduced to $1.3 \mathrm{ml}$. Approximatly $3 \mathrm{~g}$ frozen leaves sample was ground in a mortar and pestle in liquid nitrogen until complete homogenization. The homogenate was transferred to $1 \mathrm{ml}$ Eppendorf tube, brought to $200 \mathrm{ul}$ with extraction buffer (50mM Tris-HCl buffer, PH 6.8 , glycerol 10\%w/v, ascorbic acid $0.1 \%$,cysteine hydrochloride $0.1 \% \mathrm{w} / \mathrm{v}$ ). Centrifugation at $18000 \mathrm{rpm}$ for about $30 \mathrm{~min}$ was carried out. Protein in the supernatant was estimated according to the method of Bradford (1976) using bovine serum albumin as a standard. Protein content was adjusted to $2 \mathrm{mg} / \mathrm{ml}$, then used for protein analysis on a $12.5 \%$ polyacrylamide slab gel in the presence of $0.1 \%$ sodium dodocyl sulfate (SDS) as described by Okuno\&Furusawa (1979). Gel was fixed with $10 \%$ acetic acid in a $45 \%$ methanol solution 
overnight.Protein was visualized by silver staining. Molecular weight markers used in SDS- PAGE were $(116,66,45,35) \mathrm{KD}$.

\section{RESULTS}

Applications of different salts $\left(\mathrm{KH}_{2} \mathrm{PO}_{4}, \mathrm{KCl}, \mathrm{K}_{2} \mathrm{CO}_{3}\right)$ and the fungicide Master $25 \%$ to squash plants grown under greenhouse conditions were studied .

\section{Greenhouse experiment}

Table(1) shows the effects of various concentration of different salt treatments either as pre- or post inoculation with $S$. fuliginea on squash leaves. Disease severity decreased on new leaves as compared with untreated control. The most effective treatments were $\mathrm{K}_{2} \mathrm{CO}_{3}, \mathrm{KCl}$, and $\mathrm{KH}_{2} \mathrm{PO}_{4}$, respectively. The magnitude of reduction was higher in the pre inoculation treatments .

Table (2) shows significant reduction in number and size of colonies per leaf when sprayed with the salts at the high concentration $(750 \mathrm{ug} / \mathrm{ml})$. Variable results were observed for different salts at different concentrations, though reductions in disease severity compared with the control . were observed . pre-inoculation applications resulted in reduced number of diamater of colonies. Fungicide application as pre- and post inoculation treatments was more effective in $S$. fuliginea control under greenhouse conditions .

Table 1. Effect spraying squash leaves with different salts on infection with $S$. fuliginea.

\begin{tabular}{|c|c|c|c|}
\hline \multirow{3}{*}{ Treatment } & \multirow{3}{*}{$\begin{array}{c}\text { Concenteration } \\
\mathrm{Ug} / \mathrm{ml}\end{array}$} & \multicolumn{2}{|c|}{ Disease severity $\%$} \\
\hline & & \multicolumn{2}{|c|}{ Time } \\
\hline & & After inoculation & Before inoculation \\
\hline \multirow{3}{*}{$\mathrm{KH}_{2} \mathrm{PO}_{4}$} & 250 & 37.3 & 26.6 \\
\hline & 500 & 32.0 & 20.0 \\
\hline & 750 & 28.0 & 14.7 \\
\hline \multirow{3}{*}{$\mathrm{KCL}$} & 250 & 36.0 & 24.0 \\
\hline & 500 & 30.6 & 18.6 \\
\hline & 750 & 26.6 & 13.3 \\
\hline \multirow{3}{*}{$\mathrm{K}_{2} \mathrm{CO}_{3}$} & 250 & 33.3 & 20.0 \\
\hline & 500 & 29.3 & 18.6 \\
\hline & 750 & 25.3 & 12.0 \\
\hline Fungicide & Prochloraz $1 \mathrm{ml}$ & 10.6 & 4.5 \\
\hline Control & ---------------- & 46.7 & 46.7 \\
\hline \multirow{3}{*}{ L.S.D 0.05} & Treat. $=0.98$ & Time $=0.72$ & \multirow{2}{*}{ Time $x$ Conc. $=1.97$} \\
\hline & Conc. $=1.42$ & Time $x$ Treat. $=\mathrm{ns}$ & \\
\hline & $\begin{array}{c}\text { Treat } \mathrm{x} \text { conc. }= \\
\mathrm{ns}\end{array}$ & \multicolumn{2}{|c|}{ Treat. $x$ Conc. $x$ Time $=$ ns } \\
\hline
\end{tabular}


Table 2. Effect spraying squash leaves with different salt on number and colony diamater of S. fuliginea in greenhouse.

\begin{tabular}{|c|c|c|c|c|c|}
\hline \multirow[b]{2}{*}{ Treatment } & \multirow{2}{*}{$\begin{array}{c}\text { Concenteration } \\
\mathrm{ug} / \mathrm{ml}\end{array}$} & \multicolumn{2}{|c|}{ Av. Number of colony/leaf } & \multicolumn{2}{|c|}{ Av.Colony diameter (cm) } \\
\hline & & $\begin{array}{c}\text { After } \\
\text { inoculation }\end{array}$ & $\begin{array}{c}\text { Before } \\
\text { inoculation }\end{array}$ & $\begin{array}{c}\text { After } \\
\text { inoculation }\end{array}$ & $\begin{array}{c}\text { Before } \\
\text { inoculation }\end{array}$ \\
\hline \multirow{3}{*}{$\mathrm{KH}_{2} \mathrm{PO}_{4}$} & 250 & 27.4 & 21.5 & 0.89 & 0.61 \\
\hline & 500 & 18.7 & 12.3 & 0.78 & 0.46 \\
\hline & 750 & 13.3 & 9.9 & 0.46 & 0.37 \\
\hline \multirow{3}{*}{$\mathrm{KCl}$} & 250 & 25.2 & 21.2 & 0.86 & 0.86 \\
\hline & 500 & 14.7 & 11.8 & 0.78 & 0.61 \\
\hline & 750 & 11.5 & 6.9 & 0.61 & 0.46 \\
\hline \multirow{3}{*}{$\mathrm{K}_{2} \mathrm{CO}_{3}$} & 250 & 22.9 & 20.4 & 0.86 & 0.78 \\
\hline & 500 & 13.3 & 9.5 & 0.78 & 0.46 \\
\hline & 750 & 9.3 & 6.2 & 0.46 & 0.37 \\
\hline Fungicide & Prochloraz $1 \mathrm{ML}$ & 5.9 & 4.8 & 0.43 & 0.34 \\
\hline Control & |------------- & 42.3 & 42.3 & 1.2 & 1.2 \\
\hline \multirow{7}{*}{ L.S.D 0.05} & Treat. $=$ & \multicolumn{2}{|c|}{0.85} & \multicolumn{2}{|c|}{0.026} \\
\hline & Conc. $=$ & \multicolumn{2}{|c|}{1.14} & \multicolumn{2}{|c|}{0.047} \\
\hline & Treat. $\times$ Conc. $=$ & \multicolumn{2}{|c|}{ ns } & \multicolumn{2}{|c|}{ ns } \\
\hline & Time $=$ & \multicolumn{2}{|c|}{0.61} & \multicolumn{2}{|c|}{0.022} \\
\hline & Time $\times$ Treat. $=$ & \multicolumn{2}{|c|}{ ns } & \multicolumn{2}{|c|}{ ns } \\
\hline & Time $\times$ Conc $=$ & \multicolumn{2}{|c|}{1.38} & \multicolumn{2}{|c|}{0.062} \\
\hline & Treat. $\mathrm{x}$ Time $\mathrm{xConc} .=$ & \multicolumn{2}{|c|}{ ns } & \multicolumn{2}{|c|}{0.088} \\
\hline
\end{tabular}

\section{Protein extraction and electrophoretic analysis}

Mildewed squash plants at the of 3-4 leaves growth stage were sampled for protein analysis (Table 3). Composite leaves extracts were subjected to electrophoresis for 6 hours. Extracts of non-sprayed mildewed leaves showed 11 bands with molecular weights ranging between (35-109 KD).The fungicide Prochloraz - treated leaves and those sprayed with potassic salts, increased the number of separated bands being more pronounced in the fungicide treatments. The latter revealed 16 bands with molecular weights ranging between 34 and 118 KD, compared to the control(35-109 KD). It is obvious, however, that the fungicide treatment caused a distinct absence of a protein band, with a molecular weight $35 \mathrm{KD}$, contrary to the rest of treatments and control. 
Table 3. Electrophoritic analysis of soluble proteins of different treatment.

\begin{tabular}{|c|c|c|c|c|c|c|}
\hline \multirow[b]{2}{*}{ KD } & \multicolumn{6}{|c|}{ Amount \% } \\
\hline & $\begin{array}{l}\text { Protein } \\
\text { marker }\end{array}$ & Fungicide & $\mathrm{KH}_{2} \mathrm{PO}_{4}$ & $\mathrm{KCL}$ & $\mathrm{K}_{2} \mathrm{CO}_{3}$ & Control \\
\hline 118 & & 0.17 & & & 0.95 & \\
\hline 116 & 20.02 & & & 1.12 & & \\
\hline 112 & & & & & 1.26 & \\
\hline 109 & & 0.26 & & & & 3.34 \\
\hline 107 & & & 4.65 & 6.92 & & \\
\hline 101 & & 0.98 & & & & \\
\hline 98 & & 0.24 & & & 5.61 & \\
\hline 96 & & 0.39 & & & 0.63 & \\
\hline 94 & & & & & 0.93 & \\
\hline 93 & & & & & & 4.84 \\
\hline 92 & & & & & 0.81 & \\
\hline 89 & & 3.64 & & & & \\
\hline 87 & & & & & 4.29 & 4.24 \\
\hline 85 & & & 8.26 & 6.47 & & \\
\hline 70 & & 4.81 & & & & 9.86 \\
\hline 69 & & & & & 8.55 & \\
\hline 68 & & & 9.25 & 9.68 & & \\
\hline 66 & 41.85 & & & & & \\
\hline 63 & & & & & & 3.19 \\
\hline 62 & & & 2.35 & & 3.31 & \\
\hline 61 & & & & 2.79 & & \\
\hline 59 & & & & 3.34 & & \\
\hline 58 & & & 6.80 & & & 17.02 \\
\hline 57 & & 15.06 & & & & \\
\hline 56 & & & 14.56 & & 14.94 & \\
\hline 55 & & & & 16.15 & & \\
\hline 53 & & 2.78 & & & & \\
\hline 52 & & & & & & 8.06 \\
\hline 51 & & 8.50 & 9.95 & 9.56 & 8.09 & \\
\hline 49 & & & 4.58 & & & \\
\hline 48 & & & & 3.60 & & \\
\hline 47 & & & & & & 0.58 \\
\hline 45 & 22.63 & & & & & \\
\hline 44 & & & & & & 7.22 \\
\hline 43 & & 7.33 & 6.70 & 6.80 & 9.91 & \\
\hline 42 & & 0.83 & & & & \\
\hline 41 & & & 3.56 & 2.81 & & \\
\hline 40 & & 6.20 & & & & \\
\hline 38 & & 12.62 & & 17.03 & 27.42 & 27.94 \\
\hline 37 & & 21.22 & 16.72 & & & \\
\hline 35 & 15.50 & & 12.62 & 13.75 & 13.29 & 13.74 \\
\hline 34 & & 14.99 & & & & \\
\hline
\end{tabular}

Although the potassic salts showed less effect in increasing the number of protein bands ,the highest effect, however, may be considered for potassium carbonate. The latter showed 14 bands, followed by potassium chloride (13 bands) and potassium monobasic phosphate (12 bands). It could be recognized that the salt treatments caused disappearance of bands with molocular weights of 70 and 109 KD compared to the 
control. Protein analysis Table (3) showed as well the detected common proteins with molecular weights and protein bands (51 and $43 \mathrm{~K} . \mathrm{D}$ ) in treatment with $\mathrm{KH}_{2} \mathrm{PO}_{4} \& \mathrm{KCl}$ and $\mathrm{K}_{2} \mathrm{CO}_{3}$, Treatment with fungicide showed, however, a higher number of protein bands compared with control and different salt, showing unique bands with molecular weight of $101,89,57,53,40$ and 34 K.D .

\section{DISCUSSION}

The first systematic enquiry into induced resistance was made by Ross (1961). Induced disease resistance has been adopted as a general term and defined as 'the process of active resistance dependent on the host plant's physical or chemical barriers, activated by biotic or abiotic inducing agents (Kloepper et al., 1992). Resistance to primary infection can result from the presence of preformed defensive barriers (Osbourn, 1996), but often depends on inducible resistance mechanisms, where the infecting pathogen triggers defense responses through the release of elicitors which, in turn, lead to the expression of novel anti-pathogenic activities (Hammond-Kosack \&Jones, 1996).

Chemicals,such as salicylic, polyacrylic, and fatty acids, inorganic salts, as well as physical stimuli (wounding, UV,B radiation, osmotic shock, low temperature, water deficit and excess), can be involved in induction of resistance .

In the present study, the control of squash powdery mildew with non traditional methods,such as mineral salts sprays, compared with the recommended fungicides, was considred. The results showed that foliar applications of potassium salts (750ppm) in the form of acid phosphate, chloride and carbonate either before or after leaf inoculation gave promising disease control as compared with the fungicide prochloraz (Master 25\%). The treatments in concern gave reassembled disease control, but not as equal as the fungicide, being more pronounced for the Kcarbonate followed by $\mathrm{K}$-chloride and $\mathrm{K}$ - acid phosphate. Evaluation was based primarily on the number and the size of the fungal colony. These results are in accordance, in part, with those reported by Reuveni (1995). Results obtained on the mode of action of phosphate salts for controlling powdery mildew, has been attributed to the possible increase in the synthesis of host metabolites (Yoshikaw, 1978 ). The phosphate salts were reported to induce systemic resistance to anthracnose in cucumber. This activity may involve the sequestration of calcium ions, which could disrupt the cell wall and cause the release of defence-inducing cell wall fragments (Gottstein \& Kuc, 1989). Calcium-binding organic acids such as oxalates also induced resistance to anthracnose in cucumber (Doubrava et al., 1988). 
In this regard, the present study showed a remarkable effect of salts on protein metabolism as shown by the different bands separated by electrophoresis. Molecular masses of polypeptides were shown to range in size from 118 to $34 \mathrm{KD}$ on SDS- PAGE. Moreover, the polypeptides accumulation and pattern were changed by treatment. It is observed that the fungicide and $\mathrm{K}_{2} \mathrm{CO}_{3}$ treatments resulted in larger number of bands than $\mathrm{KCl}, \mathrm{KH}_{2} \mathrm{PO}_{4}$ or the control. The biological functions of such stress induced proteins have been studied extensively and some of them were identified as chitinases and B-1,3 glucanases in many plant species . Christ \& Mosinger (1989) attributed induced resistance against Peronospora tabacina and Phytopthora infestans to both chitinase and B- 1,3 glucanase activities. Meanwhile, the rapid absorption of phosphates by the plant tissues and their extreme mobility within the tissues as well as their characteristic in stimulating plant growth, as shown in previous studies on cucumber and maize (Reuveni et al ., 1995). Their low cost, low animal toxicity, comparative environmental safety and nutrient value make them ideal foliar fertilizer, which should be considered for application in the field for disease control.

\section{REFERENCES}

1. Abood, J. K., D.M. Losel, and P.G. Ayres. 1991. Lithium chloride and cucumber powdery mildew infection. Plant Pathol., 40:108-117.

2. Ahmed, E.A., H.S. IbnOaf, M.E. Suliman, A.E. El-jack, and Y.F. Mohamed. 2000. Selection of snake melon lines (Cucumis melo var. flexuosus) resistant to powdery mildew Sphaerothec afuliginea (Schlecht. Ex Fr. Poll) in Sudan.CGC Report, 23:27-29.

3. Bourlarye, F., B. Nicole, J.Mc. David, L. Coroline, S. Armand, and R.B.Richard. 2005. Suppression of induced resistance in cucumber through disruption of the flavonoid pathway. Phytopatholgy , 95,114-123.

4. Bradford, M. M. 1976. A rapid and sensitive method for the quantification of microgram quantites of protein dye binding. Anal. Biochem, 72:248-254.

5. Christ, U., and E. Mosinger. 1989. Pathogensis -related proteins of tomato : I induction by Phytophthora infestans and other biotic and abiotic inducers and correlations with resistance. Physiol. Mol. Plant Pathol., 35:53-65.

6. Descalzo, R.C., J.E. Rohe, and B. Mauza. 1990.Comparative efficacy of induced resistance for selected diseases of greenhouse cucumber.Can. J. Plant Pathol .,12: 16-24.

7. Doubrava, N., R. Dean, and J. Kuc. 1988. Induction of systemic resistance to anthracnose caused by Colletotricum lagenarium in cucumber by oxalates and extracts from spinach and rhubarb leaves. Physiol .Mol. Plant Pathol., 33:69-79. 
8. Gottstein, H. D., and J.A. Kuc. 1989. Induction of systemic resistance to anthracnose in cucumber by phosphates. Phytopathology 79:176-179.

9. Hammond-Kosack, K.E. and J.D.G. Jones. 1996. Resistance gene dependent plant defense responses. The Plant cell 8: 1773-1791.

10. Kloepper, J.W., S. Tuzun and J.A. Kuc. 1992. Proposed definitions related to induced disease resistance. Biocontrol Science and Technology 349-351.

11. Laemili, U.K. 1970. Cleavage of structural proteins during the assembly of the head of Bacteriophage T4. Nature, 227: 680-685.

12. Mucharromah, E. and J. Kuc. 1991. Oxalate and phosphates induce systemic resistance against disease caused by fungi, bacteria and viruses in cucumber . Crop. Prot., 10:265-270.

13. NaM Jun Kang. 2008. Inhibition of powdery mildew development and activation of antioxidant enzymes by induction of oxidative stress with foliar application of mixture of riboflavin and methionine in cucumber. Scientia Horticulturae., 118:181-188.

14. Okuno, T., and I. Furusawa. 1979. RNA polymarse activity and protein synthesis in borme mosaic virus infected protoplasts .Virology, 99:218-225.

15. Osbourn, A.E. 1996. Preformed antimicrobial compounds and plant defense against fungal attack. The Plant Cell 8: 1821-1831.

16. Reuveni, M.,V. Gapov, and R. Reuveni. 1995. Suppression of cucumber powdery mildew Sphaerotheca fuliginea by foliar sprays of phosphates and potassium salts. Plant Pathol., 44:31-39.

17. Ross , A.F. 1961b. Systemic acquired resistance induced by localized virus infections in plants. Virology, 14: 340-358.

18. Sequeira, L. 1983. Mechanisms of induced resistance in plants. Annu. Rev. Microbiol. 79.

19. Sherf, A.F., and A.A. MacNab. 1986. Vegetable diseases and their control. $2^{\text {nd }}$ ed . John Wiley \& Sons, New York. 728 pp .

20. Yoshikawa, M. 1978). Diverse mode of action of biotic and abiotic phytoalexin elicitors. Nature, 257: 546-47.

21. Ziv, O., and T.A. Zitter. 1992. Effects of bicarbonates and film- forming polymers on cucurbit foliar diseases. Plant Dis., 76:513-517 


\section{الاملاح المعدنية ومكافحة البياض الدقيقى فى الكوسة}

نجلاء عبد الباقى سلام مهنا سهام سمير محمد رجب جهاد محمد محمد

$$
\text { معرة بحوث أمراض النبات - مركز البحوث الزراعيه - الجبزه }
$$

تمت در اسه مكافحة مرض البياض الاقيقى فى الكوسه المسبب عن سفيروسيكا فلجينيا باستخدام املاح فوسفات البوتاسيوم وكلوريد البوتاسيوم وكربونات البوتاسيوم مقارنه بلجحد المبيدات .

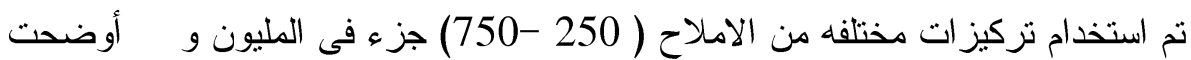
الدر اسه أن أفضل التركيزات لهذه الاملاح هى 750 جزء فى المليون. كما اوضحت

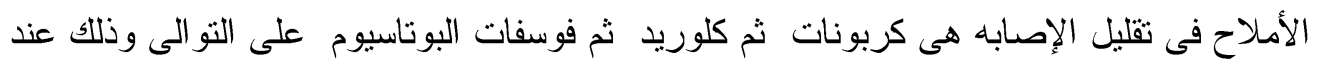

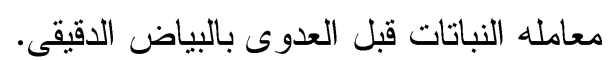
كما أوضحت نتائج الفصل الكهربى للبروتينات وجود إختلاف بين المعاملات فى عدد البروتينات ونسبه تكونهامقارنةً بالنبات الغير معامل حيث يلاحظ أن النباتات المصابه تكون نسبه

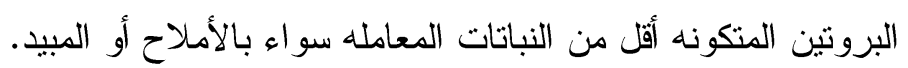

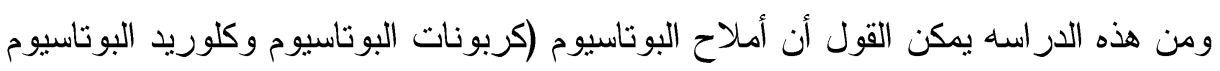

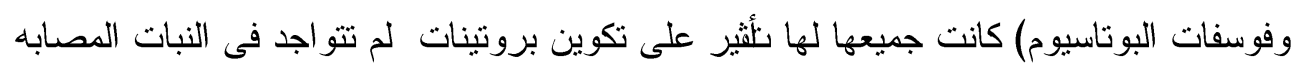

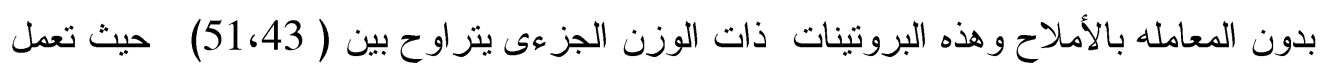

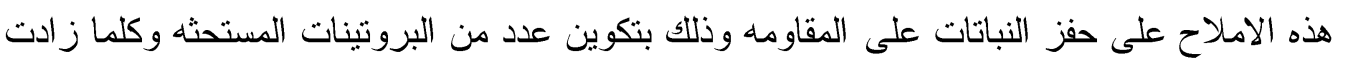

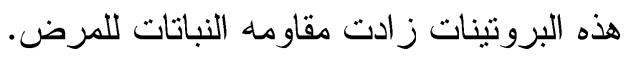

